\title{
Strategi Public Relations PT X dalam Menghadapi Persaingan Bisnis Otomotif
}

\author{
Erika Laurencia, Yugih Setyanto \\ erika.915160050@stu.untar.ac.id,yugihs@fikom.untar.ac.id \\ Fakultas Ilmu Komunikasi Universitas Tarumanagara
}

\begin{abstract}
Cars are one of many transportation that makes it easier for people to go on with their daily lives and meet the need of the communities and the most popular vehicles amongst the people that caused the intense competition in automotives industry. Public Relations has an importan role in the competitive automotives business. This research was conducted to explain PT X's public relations strategy in dealing with the competitive automotive business. The approach used in this research is case study analysis by doing observation and interview to few parties involved in company's strategy. The conclusion of this research is all public relations strategies are used by PT X in dealing with competitors, many parties also participated in this public relations strategy, because PT X is a huge company therefore there are several departement that deal helps with for the strategy to be effective.
\end{abstract}

Keywords: communication, public relations, public relations strategy

\begin{abstract}
Abstrak
Mobil merupakan salah satu transportasi yang memudahkan masyarakat melakukan kegiatan sehari-hari, dan dapat memenuhi kebutuhan masyarakat. Mobil merupakan kendaraan yang paling digemari oleh masyarakat. Hal tersebut yang membuat perkembangan Industri Otomotif mengalami persaingan yang ketat. Public Relations memiliki peranan penting dalam persaingan bisnis otomotif. Penelitian ini dilakukan untuk menjelaskan strategi public relations PT X dalam menghadapi persaingan bisnis otomotif. Pendekatan yang digunakan dalam penelitian ini adalah menggunakan metode studi kasus dengan pendekatan kualitatif yang merupakan deskriptif. Dalam penelitian ini penulis melakukan dengan cara observasi dan wawancara beberapa pihak yang ikut serta dalam strategi tersebut. Kesimpulan dari penelitian ini adalah seluruh strategi public relations digunakan oleh PT X dalam menghadapi para competitor, tetapi banyak pihak yang ikut serta dalam strategi public relations ini, karena PT $\mathrm{X}$ merupakan perusahaan besar sehingga terdapat beberapa bagian yang menangani agar efektif.
\end{abstract}

Kata Kunci: komunikasi , public relations, strategi public relations

\section{Pendahuluan}

Transportasi digunakan untuk memudahkan manusia dalam melakukan aktivitas sehari-hari. Oleh karena itu,transportasi sangat dibutuhkan oleh masyarakat untuk mobilitas setiap hari nya. Dengan kebiasaan menggunakan kendaraan pribadi itulah yang menjadi peluang bagi perusahaan otomotif untuk mengembangkan industrinya.

Pertumbuhan manufaktur di Indonesia bisa berkembang cepat dikarenakan kepemilikan mobil per-kapita yang rendah, serta semakin bertumbuhnya kelas menengah, dan biaya tenaga kerja yang murah. Dan juga minat masyarakat terhadap otomotif hal tersebut merupakan salah satu faktor penyebab manufaktur di Indonesia dapat cepat berkembang. 
Serta perusahaan-perusahaan manufaktur mobil dari Jepang merupakan para pemain dominan dalam industri manufaktur Indonesia seperti perusahaan Toyota, Daihatsu, Suzuki, Mitsubishi, Honda, dan Nissan. Serta ada perusahaan manufaktur dari China yang baru masuk ke dalam industri otomotif di Indonesia seperti Wuling, DFSK.

Berdasarkan latar belakang di atas, hal tersebut yang membuat penulis tertarik untuk melakukan penelitian "Strategi Public Relations PT X Dalam Persaingan Bisnis Otomotif". Dalam penelitian ini, peneliti menggunakan beberapa teori yaitu teori komunikasi, public relations, serta strategi public relations.

Mulyana (2009) mendefinisikan komunikasi sebagai suatu komunitas (community), artinya di dalam sekelompok orang yang berkumpul atau ingin bersama untuk mencapai tujuan tertentu dan mereka berbagai makna dan sikap. Selanjutnya, Cutlip, Center \& Brown menyebutkan cara untuk terbangunnya pemahaman dan pengertian penerimaan serta kerjasama antar perusahaan bersama berbagai publiknya merupakan fungsi manajemen yang mendukung untuk terbentuknya komunikasi yang saling pengertian, pemahaman, penerimaan dan kerja sama antara organisasi dengan berbagai publiknya, (Cutlip, Center \& Brown, 2000).

Untuk mengembangkan strategi public relations yang tepat, praktisi public relations perlu untuk selalu melihat kembali analisa situasi yang telah dikembangkan. Analisa situasi memberikan gambaran masalah yang dihadapi, tujuan memberikan gambaran hasil yang diinginkan, dan identifikasi publik memfokus pada publik sasaran yang hendak diraih dari program public relations. Dengan demikian, strategi membantu mengembangkan rencana bagaimana cara berkomunikasi secara efektif untuk mencapai tujuan yang diharapkan, yakni dalam mempengaruhi publik sasaran. Intinya, strategi menjelaskan apa yang akan dikatakan.

PENCILS merupakan singkatan dari bauran Public Relations yang memiliki definisi strategi dari public relations pada saat mengerjakan perannya, adalah sebuah strategi Public Relations dalam melaksanakan perannya dan didalam PENCILS memiliki komponen. Ruslan dalam Ardianto (2009), mendefinisikan komponennya sebagai berikut:

1. Publications (publikasi): Publikasi merupakan cara public relations dalam menyebarkan informasi, gagasan, atau ide kepada khalayaknya. Setiap fungsi dan tugas public relations adalah memberikan informasi melalui berbagai media tentang aktivitas atau kegiatan perusahaan atau organisasi. Publikasi sangat diperlukan untuk menginformasikan berbagai kegiatan yang akan digelar oleh PT $\mathrm{X}$.

2. Event (acara): Merupakan bentuk kegiatan yang dilakukan oleh seorang public relations dalam proses penyebaran informasi kepada khalayak. Merencanakan sebuah event yang dimaksudkan untuk memperkenalkan produk dan layanan perusahaan kepada publik. Hal ini berkaitan dengan penyusunan program acara, dapat dibedakan menjadi: Calender Event-Regular Event (Kegiatan Rutin), Special Event - Kegiatan khusus dan dilaksanakan pada momen-momen tertentu, contoh ulang tahun perusahaan, launching (peluncuran) produk; dan Moment Event - kegiatan yang bersifat momentum.

3. News (Pesan/Berita): Pesan yang disampaikan untuk masyarakat secara langsung maupun tidak langsung yang bertujuan untuk mendapatkan respon yang baik dan penerimaan dari masyarakat.

4. Community Involvement (Hubungan dengan Khalayak): Hubungan yang terbentuk oleh masyarakat. 
5. Inform or Image (Mengumumkan Citra): Ini merupakan aktivitas untuk memperoleh tanggapan yang positif yaitu citra yang baik dengan cara memberitahukan kepada masyarakat.

6. Lobbying and Negotiation (Teknik Lobi dan Negosiasi): Kegiatan public relations berupa rencana jangka pendek maupun jangka panjang yang berupaya untuk menyusun anggaran yang diperlukan.

7. Social Responsibility: Wacana yang berupaya dalam mengambil peran secara bersamaan dalam melakukan kegiatan dalam upaya sedang mengemuka di dunia bisnis atau perusahaan dalam rangka mensejahterakan masyarakat.

Peneliti menggunakan penelitian terdahulu yaitu Jessica Tamara dan Yugih Setyanto yang berjudul Strategi Public Relations dalam Membangun Brand Image Jamu (Studi pada Suwe Ora Jamu Kedai Jamu \& Kopi). Dalam Jurnal Komunikasi. Vol. 2, No. 2, desember 2018.

\section{Metode Penelitian}

Kegiatan pengumpulan data yang dilakukan oleh penulis terdiri dari beberapa sumber data, antara lain: data primer dan data sekunder. Data primer dapat diartikan sebagai data yang dikumpulkan dari sumber-sumber asli (Kuncoro dalam Hamid 2011). Ada beberapa macam metode pengumpulan data menurut Sugiyono (2010) yang berkaitan dengan penelitian ini, antara lain:

\section{Observasi}

Menurut Nasution dalam Sugiyono (2010) menyatakan bahwa observasi merupakan dasar dari semua ilmu pengetahuan. Sugiyono (2010) menyatakan bahwa observasi dapat dilakukan dengan dua cara, yaitu observasi partisipatif dan nonpartisipatif. Observasi partisipatif merupakan observasi yang dilakukan dengan cara peneliti terlibat langsung dalam kegiatan sehari-hari orang atau individu yang sedang diamati atau yang digunakan sebagai sumber penelitian. Sedangkan untuk non partisipan adalah observasi yang dilakukan dimana dengan cara peneliti datang ke tempat penelitian tersebut, tetapi tidak terlibat dalam kegiatan tersebut, peneliti hanya menjadi sekedar pengamat.

Dalam penelitian ini, peneliti akan melakukan kegiatan observasi secara partisipan, dimana penulis melakukan penelitian secara langsung menjadi bagian dari perusahaan, dan melakukan pengamatan.

\section{Wawancara}

Wawancara merupakan pertemuan antara dua orang untuk bertukar informasi dan ide melalui tanya jawab sehingga dapat dikonstruksikan makna dalam suatu topik tersebut (Estenberg dalam Sugiyono 2010). Estenberg dalam Sugiyono (2010) menyatakan ada beberapa macam jenis wawancara, antara lain :

1. Wawancara Terstruktur : merupakan wawancara yang digunakan sebagai teknik pengumpulan data bila peneliti telah mengetahui dengan pasti mengenai informasi yang akan diperoleh. Dalam wawancara ini, pengumpul data harus sudah menyiapkan instrumen penelitian seperti pertanyaan-pertanyaan tertulis yang sudah disiapkan untuk bertanya kepada narasumber.

2. Wawancara tidak terstruktur: merupakan wawancara yang bebas dimana peneliti tidak menggunakan pedoman pertanyaan wawancara yang telah tersusun secara sistematis dan lengkap untuk pengumpulan datanya. 


\section{Data Sekunder}

Data sekunder adalah data yang dapat dikumpulkan oleh pihak lain (Kuncoro dalam Hamid, 2011). Data sekunder merupakan data tambahan dimana digunakan penulis untuk menambahkan keterangan lebih jelas pada data primer. Teknik Pengelolaan dan analisa yang digunakan oleh penulis, seperti yang dikatakan oleh Miles dan Huberman dalam Sugiyono (2010) mengemukakan bahwa aktivitas dalam analisis data kualitatif dilakukan secara interaktif dan berlangsung secara terus menerus sehingga datanya sudah jenuh. Aktivitas dalam analisis data antara lain:

(1)Reduksi data, merupakan proses merangkum, memilih hal-hal pokok, fokus pada hal-hal penting, dicari tema dan polanya serta membuang yang tidak perlu. Penulis melakukan penelitian yang memfokuskan topik yang ingin ditanyakan oleh key informan. (2) Penyajian data dapat dilakukan dalam bentuk uraian singkat, teks naratif, bagan, flowchart, hubungan antar kategori. Dengan menyajikan data, maka akan memudahkan untuk memahami apa yang terjadi, merencanakan langkah selanjutnya berdasarkan apa yang telah dipahami.

Penyajian data yang penulis gunakan dalam bentuk uraian singkat yang merupakan penjelasan dari hasil wawancara dengan key informan.

Penarikan Kesimpulan atau Verifikasi

Penarikan kesimpulan dapat bersifat sementara, tetapi akan berubah seiring dengan adanya bukti-bukti yang kuat yang mendukung pada tahap pengumpulan data berikutnya.

Pada proses pengolahan dan analisis data penelitian ini, peneliti terlebih dahulu merangkum dan memilah hal-hal pokok dalam penelitian ini. Dengan demikian data yang telah dipilih akan memberikan gambaran yang lebih jelas. Setelah memilah data hasil penelitian, peneliti akan menyajikan data berupa teks naratif sehingga akan memudahkan peneliti untuk memahami hasil penelitian. Dan yang terakhir adalah peneliti akan menarik kesimpulan dari setiap hasil penelitian yang didapatkan sehingga hasil penelitian yang awalnya samar-samar menjadi lebih jelas.

\section{Hasil Temuan dan Diskusi}

Komunikasi merupakan bagian penting bagi kelangsungan hidup perusahaan dan komunikasi merupakan cara untuk berinteraksi dengan publik eksternal dan publik internal perusahaan, dengan adanya komunikasi segala sesuatu berjalan sesuai dengan tujuan yang diharapkan. Dalam PT X komunikasi sangat berperan penting dalam hal perkembangan PT X sehingga divisi nya sendiri, sudah ada khusus corporate planning and communication $(C P C)$ di bawahnya yang mengelola setiap hari adalah dari public relations department mengelola komunikasi dari sisi eksternal yang berkaitan media jurnalis relation dan internal komunikasi antara karyawan itu sendiri melalui forumforum yang ada atau melalui tools yang ada yaitu intranet, melalui social media sangat penting sehingga ada direktornya ada divisi nya sehingga dikelola secara harian ada department atau Person In Charge (PIC) yang mengelola komunikasi PT X

Menurut temuan penulis saat melakukan observasi karena PT X merupakan perusahaan besar, sehingga terbagi beberapa department sehingga lebih fokus dan terorganisasi, sehingga Public Relations Department ini tidak hanya menangani banyak hal, melainkan beberapa department yang berbeda, dan ikut serta dalam kegiatan yang juga berhubungan dengan public relations. Menurut hasil observasi dan wawancara, peran dan fungsi public relations di PT X, memanage berita- berita seputar PT X yang dipublikasikan di media-media baik media online, media cetak, Televisi, 
sosial media baik dalam skala nasional maupun regional dan memprofite analisa terkait berita-berita yang ada di masyarakat tentang PT X. Serta menjaga relasi dengan media-media yang ada, itu secara eksternal. Untuk secara internal fungsinya adalah menyalurkan informasi perusahaan yang menggapai semua lini perusahaan dan tersampaikan dengan baik ke karyawan dan juga mentriger informasi-informasi penting yang apa di seluruh bagian PT X sehingga dapat dipublikasikan keluar, ada fungsi dari luar ke dalam juga, informasi baik di dalam dapat dipublikasikan keluar, sedangkan informasi yang baik tentang PT X dapat tersampaikan ke karyawan, sehingga karyawan mengetahui aspek-aspek perusahaan dan bisa bangga menjadi bagian keluarga PT X.

Karena perkembangan otomotif semakin meningkat dan banyak nya para pesaing baru yang bermunculan dan menunjukkan eksistensi nya. Sehingga PT X harus memiliki strategi, strategi yang digunakan adalah strategi public relations atau yang lebih dikenal dengan bauran Public Relations atau bisa disebut PENCILS. Menurut Ruslan dalam Ardianto (2009), PENCILS memiliki komponen yaitu sebagai berikut :

Publication (Publikasi) : berdasarkan hasil analisa study mereka, menentukan media apa saja yang paling efektif untuk jenis bisnis mereka, sama tipe berita itu nya sendiri, untuk berita-berita tentang seperti kaitannya product launching, atau mengenai product ke media-media bersifat bisnis and otomotif, media online maupun cetak tetapi apabila sedang melakukan branding activity seperti misalnya acara dengan anak-anak muda youthful projects seperti Urban Fest, Musik Asik dan lainnya, tidak menutup kemungkinan mereka menyalurkan berita-berita kita ini ke media lifestyle, semua bergantung pada kebutuhan dan situasi.

Event (acara) : Any Noor (2013), mendefinisikan events adalah kegiatan untuk mengingatkan sesuatu hal yang penting sepanjang hidup manusia secara individu maupun kelompok yang terikat baik secara adat, budaya, agama, dan tradisi yang diselenggarakan untuk tujuan tertentu serta melibatkan lingkungan masyarakat yang diselenggarakan pada waktu tertentu. Berbeda dengan event yang dilakukan PT X, event tersebut merupakan kegiatan yang dilakukan oleh public relations dalam melakukan proses penyebaran informasi kepada khalayak. Merencanakan sebuah event yang dimaksudkan seperti memperkenalkan produk dan layanan perusahaan kepada publik. Public Relations mempunyai strategi lainnya dengan merancang khusus yang di pilih dalam jangka waktu, tempat, objek tertentu yang mempengaruhi opini public.

Tetapi di PT X sendiri event tidak hanya ditangani oleh public relations sendiri melainkan ada campur tangan dari bagian promotion yang ikut serta dalam merencanakan sebuah event tersebut dan merancang semua kegiatan event. Karena sebuah event akan membutuhkan beberapa pihak untuk keberlangsungan event tersebut. Event yang digunakan oleh PT X ada 2 yaitu kalender Event dan Reguler Event.

kalender Event, seperti hasil temuan observasi penulis selama berada di PT X dan bertanya tanya dengan ke beberapa orang sehingga, penulis mengetahui bahwa Calender of Event adalah sebuah rancangan kegiatan event apa saja yang akan dilakukan dalam setahun oleh PT X, salah satu event yang dikenal oleh kalangan masyarakat seperti Astec Open, Gaikindo International Auto Show (GIIAS), Indonesia Master

Reguler Event, sedangkan 
Reguler of Event adalah rancangan kegiatan yang termasuk dalam Calender of Event tetapi event tersebut selalu dan pasti diadakan setiap tahunnya, salah satu event nya yaitu Urban Fest, Terios 7 Wonders, Astec Open, Indonesia Master.

News (Pesan/Berita) : Informasi yang dikomunikasikan kepada khalayak yang dapat disampaikan secara langsung maupun tidak langsung. Informasi yang disampaikan bertujuan agar dapat diterima oleh khalayak dan mendapatkan respon yang positif. public relations strategi nya yang digunakan oleh $\mathrm{PT} \mathrm{X}$ adalah mengeluarkan release secara berkala, dimana PT X tidak mau melewatkan, ibaratnya satu hari PT X kosong dengan pemberitaan, tentunya dengan pemberitaan positif.

Community Involvement (Hubungan dengan Khalayak): Sebuah relasi yang dibangun khalayak (stakeholder, stockholder, media, masyarakat di sekitar perusahaan, dan lain-lain. Penemuan penulis selama melakukan observasi menyimpulkan bahwa Community Involvement dilakukan dengan cara melakukan mudik bersama dengan klub-klub mobil $\mathrm{X}$, tujuannya untuk mempererat komunikasi PT X dengan klub-klub mobil yang menggunakan mobil $X$, salah satunya ada melakukan media test drive, dimana mencoba product yang baru diluncurkan untuk menguji kualitas produk.

Inform or Image (Mengumumkan Citra) : Ini merupakan salah satu fungsi public relations dimana memberitahukan sesuatu kepada publik atau menarik perhatian publik sehingga memperoleh tanggapan yang baik berupa citra yang positif. Dengan segala aktivitas usaha yang dilakukan. Citra yang terbentuk dapat berupa citra positif maupun citra negatif, tergantung dari upaya apa saja yang dilakukan oleh sebuah perusahaan untuk menciptakan dan mempertahankan citra positif, demi keberlangsungan sebuah perusahaan. Menurut hasil temuan penelitian PT X menggunakan media gathering, media test drive, dan media visit sebagai salah satu untuk membentuk citra positif perusahaan.

Lobbying and Negotiation (Teknik Lobi dan Negosiasi): Kegiatan public relations berupa rencana jangka pendek maupun jangka panjang yang berupaya untuk menyusun anggaran yang diperlukan.Misalnya seperti mengadakan press conference recall terkait connecting rod pada mesin kendaraan. Disampaikan terlebih dahulu ke media-media yang di undang ke dalam press conference tersebut jangan menganggap hal tersebut sebagai negative, justru PT X terbuka dan mengadakan press conference agar customer dan semua pihak mengetahui niat baik PT X untuk menjaga safety dan kepedulian terhadap pelanggannya..

Social Responsibility, merupakan hal yang sangat terkenal terutama di dunia bisnis atau perusahaan. Wacana ini digunakan oleh perusahaan dalam rangka mengambil peran untuk secara bersama melaksanakan aktivitasnya dalam rangka mensejahterakan masyarakat. Menurut hasil temuan penulis, Public Relations PT X hanya menangani Social Responsibility yang berupa Plant Visit dari Universitasuniversitas serta sekolah-sekolah yang datang melakukan kunjungan ke pabrik.

\section{Simpulan}

Dalam penelitian yang dilakukan oleh peneliti selama menjadi partisipan observer, ada beberapa kesimpulan yang didapat oleh penulis: PT X melaksanakan seluruh Strategi Public Relations atau yang lebih dikenal dengan bauran Public Relations atau biasa yang dikenal dengan PENCILS yang terdiri dari Publications, News, Event ( Calender of Event, Regular of Event ), Community Involvement, Inform or Image, Lobbying and Negotiation, dan Social Responsibility. 
PT X memiliki strategi dimana mereka melakukan dengan cara mulai merambah kalangan milenial dengan mengadakan beberapa event-event yang disukai oleh kalangan anak muda. PT X juga selalu menjalankan komunikasi yang baik dengan khalayak seperti melakukan media gathering,media test drive, dan juga customer gathering.

\section{Ucapan Terima Kasih}

Ucapan terimakasih kepada Tuhan atas rahmat dan penyertaannya, Orang tua yang selalu memberikan semangat selama penulis mengerjakannya, dan juga serta Indra Setiawan sebagai Head Public Relations Department, Finky Veramitha sebagai Section Head, Public Relations Department, David Setyawan sebagai Section Head, Promotion Departement, dan Fauzi Arief Triwibowo sebagai Below the Line (BTL) Supervisor yang berkenan menjadi narasumber. Selain itu penulis juga ingin berterima kasih kepada sahabat penulis yang telah banyak membantu penulis dalam menyelesaikan penelitian ini dalam bentuk semangat.

\section{Daftar Pustaka}

Agung, Silih Wasesa, Jim Macnamara. (2006). Strategi Public Relations. Jakarta : PT Gramedia.

Abdul Hamid, (2009). Konsep dan Tuntutan Praktis Basis Data. Yogyakarta: Andi Any Noor. (2013). Manajemen Event. Bandung : Alfabeta Offset.

Ardianto, Elvinaro. (2009). Public Relations Praktis. Edisi pertama. Jakarta: Widya Padjajaran.

Cutlip, Scott M; Center, Allen H; Broom, Glen M (2000). Effective Public Relations 8 Edition. New Jersey. Prentice-Hall. Inc

Mulyana, Deddy. (2009). Ilmu Komunikasi Suatu Pengantar. Bandung: PT Remaja Rosdakarya

Nova, Firsan. (2011). Crisis Public Relations Bagaimana PR Menangani Krisis Perusahaan. Jakarta: Raja Grafindo Persada.

Sugiyono. (2010). Metode Penelitian Pendidikan Pendekatan Kuantitatif, kualitatif, dan $R \& D$. Bandung: Alfabeta

Tamara, Jessica dan Yugih Setyanto (2018). Strategi Public Relations dalam Membangun Brand Image Jamu (Studi pada Suwe Ora Jamu Kedai Jamu \& Kopi). Jurnal Komunikasi, Vol. 2, No. 2, Desember 2018, Hal 377-384 